Wir notieren noch zwei Spezialisierungen:

1. In 1 . Bonsscher Näherung, $\delta^{i}{ }_{l} \ll 1$ für alle $l$, sind die Streufunktionen linear in den Streuphasen, ihre Bilinearformen dementsprechend bilinear. Das heißt $\omega_{12}$ verschwindet, weil es von mindestens 3. Potenz in den Phasen ist.

2. Für skalare Teilchen ist $\delta^{1}{ }_{l}=\delta^{2}{ }_{l}$, also $a_{1}=k \cdot g=0$. Es wird dann $\omega_{0}=\omega_{11}, \omega_{12}=0, \omega_{33}=-\sqrt{ } 2 \omega_{34}$, wie es gemäß Gl. (1.4) sein muß.
Meinem verehrten Lehrer, Herrn Prof. Dr. L. WaLDmanN, darf ich für die Anregung dieser Arbeit und fördernde Kritik herzlich danken. - Herrn Prof. Dr. G. U. Schubert danke ich dafür, daß er die Voraussetzung zur Durchführung dieser Arbeit geschaffen hat. - Die technische Abwicklung meines Rechenprogrammes auf elektronischen Maschinen bei der IBM in Düsseldorf und in Stuttgart sowie am Institut für Angewandte Mathematik der Universität Mainz hat Herr Dipl.-Math. W. ThIELE übernommen. Ihm und den beteiligten Instituten danke ich. - Dem Bundesministerium für wissenschaftliche Forschung sage ich für finanzielle Unterstützung dieser Arbeit meinen verbindlichen Dank.

\title{
Simpler Formulae for the Chapman-Cowling Second Approximation to the Thermal Diffusion Factor of Binary Gas Mixtures
}

\author{
By R. K. Joshi and S. C. Saxena \\ Physics Department, University of Rajasthan, Jaipur, India \\ (Z. Naturforschg. 19 a, 314-318 [1964] ; eingegangen am 30. Oktober 1963)
}

\begin{abstract}
A scheme has been proposed for approximating the complicated second and higher CHapmanCowling approximation formulae for the thermal diffusion factor of a binary gas mixture. Expressions have been reported for the second approximation and their accuracy investigated by performing numerical calculations for the systems $\mathrm{Ar}-\mathrm{Xe}$ and $\mathrm{He}-\mathrm{Xe}$ as a function of both temperature and composition. These formulae have been further simplified by expressing them in the ascending powers of $M$, the ratio of the molecular weight of the lighter component to the heavier component, and neglecting all those terms which explicitly posses the power of $M$ greater than two. The two particular cases when either of the components is present in tracer amounts have also been investigated.
\end{abstract}

The complicated form and the poor convergence of the higher approximations to the thermal diffusion factor of a binary gas mixture, $\alpha_{\mathrm{T}}$, according to the formulation of Chapman and Cowling ${ }^{1}$ has necessitated the development of suitable schemes for simplifying rigorous expressions without any appreciable loss of accuracy. One such scheme was proposed and applied to the various types of mixtures by Saxena and Dave ${ }^{2-4}$, and SAxena, Dave and ParDESHI $^{5}$. This procedure involved the representation of the $\alpha_{T}$ expression in ascending powers of $M$, the ratio of the mass of the lighter component $\left(M_{2}\right)$ to the heavier component $\left(M_{1}\right)$, and neglect of all those terms which contained the power of $M$ greater than two. An alternative procedure can be developed

1 S. Chapman and T. G. Cowling, The Mathematical Theory of Non-uniform Gases, Cambridge University Press, 1952.

2 S. C. Saxena and S. M. Dave, Rev. Mod. Phys. 33, 148 [1961].

3 S. C. Saxena and S. M. Dave, Mol. Phys. 6, 61 [1963].

4 S. C. Saxena and S. M. Dave, Indian J. Phys. 37, 111 [1963]. based on the property that the diagonal elements of the Chapman-Cowling determinants are usually much larger than the off-diagonal elements. An indication that this scheme might prove successful for thermal diffusion was obtained from the work of SAXENA and Joshi ${ }^{6,7}$. These workers found that the simplified expressions of SAxENA et al. obtained according to the first procedure are considerably improved if the terms containing the product of two diagonal elements are also retained irrespective of their power of $M$. In this paper we apply this criterion to simplify the second approximation expression for the thermal diffusion factor $\left[\alpha_{\mathrm{T}}\right]_{2}$. It is important to note that this particular procedure has proved very successful for simplifying the second approximation expression

5 S. C. Saxena, S. M. Dave, and P. A. Pardeshi, Canadian J, Phys. 40, 1608 [1962].

6 S. C. Saxena and R. K. Joshi, Canadian J. Phys. 41, 207 [1963].

7 S. C. Saxena and R. K. Joshi, Indian J. Phys. 37, 235 [1963]. 
for the viscosity of a binary gas mixture, SAxENA and Joshi ${ }^{8}$, and the Kinara-Mason expression for $\left[\alpha_{T}\right]_{2}$, SAXENa and Joshi ${ }^{9}$.

\section{Simplified Formulae for $\left[\alpha_{\mathrm{T}}\right]_{2}$}

The second approximation expression for the binary thermal diffusion factor according to the rigorous theory of Chapman and Cowling ${ }^{1}$ is

$$
\begin{aligned}
{\left[\alpha_{\mathrm{T}}\right]_{2}=} & (5 / 2)\left[A_{00}^{(2)}\right]^{-1}\left[X_{2}^{-1} A_{01}^{(2)}\left\{\left(M_{1}+M_{2}\right) \mid 2 M_{1}\right\}^{\frac{1}{2}}\right. \\
& \left.+X_{1}^{-1} A_{0-1}^{(2)}\left\{\left(M_{1}+M_{2}\right) \mid 2 M_{2}\right\}^{\frac{1}{2}}\right],
\end{aligned}
$$

To explain the determinants $A$, let us introduce $A^{(2)}$, a determinant of order 5 whose general element is $a_{i j} ; i$ and $j$ range from -2 to +2 including zero. Now, $A_{i j}^{(2)}$ is a determinant obtained from $A^{(2)}$ by deleting the row and the column containing $a_{i j}$ and $X_{i}$ is the mole fraction of the $i$-th component. The three determinants of eq. (1) get considerably simplified if we retain only those terms which contain the product of two or more diagonal elements of the determinant $A^{(2)}$. The simplified expressions are

$$
\begin{aligned}
A_{00}^{(2)} & =a_{-2-2} a_{11}\left(a_{-1-1} a_{22}-a_{-12}^{2}\right) \\
& -a_{-2-2}\left(a_{-1-1} a_{12}^{2}+a_{22} a_{-11}^{2}\right) \\
& -a_{11}\left(a_{22} a_{-1-2}^{2}+a_{-22}^{2} a_{-1-1}\right) \\
& -a_{-1-1} a_{22} a_{1-2}^{2}, \\
A_{01}^{(2)} & =a_{-2-2} a_{-1-1}\left(a_{10} a_{22}-a_{20} a_{12}\right) \\
& -a_{22}\left(a_{-2-2} a_{-10} a_{1-1}\right. \\
& \left.\quad+a_{-20} a_{-1-1} a_{-21}\right),
\end{aligned}
$$

and

$$
\begin{aligned}
A_{0-1}^{(2)} & =a_{-2-2} a_{22}\left(a_{-10} a_{11}-a_{-11} a_{10}\right) \\
& -a_{11}\left(a_{-2-2} a_{-12} a_{20}+a_{-20} a_{-1-2} a_{22}\right) .
\end{aligned}
$$

The defining relations for the various $a_{i j}$ are given by Mason ${ }^{10}$.

The rigorous expression for $\left[\alpha_{T}\right]_{2}$ corresponding to the two limiting cases when either of the components is present in trace can also be simplified by applying the above criterion viz., by discarding all those terms which contain three or four off-diagonal elements of the determinant $A^{(2)}$. To this approximation the rigorous expression of SAXENa and DAvE ${ }^{2}$ for the case of the heavier component in trace $\left(X_{1} \rightarrow 0\right)$ assumes the following form:

$$
\begin{aligned}
{\left[\alpha_{\mathrm{T}}\right]_{2}\left(X_{1} \rightarrow 0\right) } & =\frac{5}{2 \sqrt{2}}\left[a_{-2-2}^{\prime \prime} a_{-1-1}^{\prime \prime}\left(a_{11}^{\prime} a_{22}^{\prime}-a_{12}^{\prime 2}\right)-a_{11}^{\prime} a_{22}^{\prime} a_{-1-2}^{\prime \prime 2}\right]^{-1} \\
& \cdot\left[\left(\frac{M_{1}+M_{2}}{M_{1}}\right)^{\frac{1}{2}}\left\{a_{-2-2}^{\prime \prime} a_{-1-1}^{\prime \prime}\left(a_{10} a_{22}^{\prime}-a_{20} a_{12}^{\prime}\right)\right\}\right. \\
& \left.+\left(\frac{M_{1}+M_{2}}{M_{2}}\right)^{\frac{1}{2}}\left\{a_{11}^{\prime} a_{22}^{\prime}\left(a_{-2-2}^{\prime \prime} a_{-10}-a_{-20} a_{-1-2}^{\prime \prime}\right)-a_{-2-2}^{\prime \prime}\left(a_{-11} a_{10} a_{22}^{\prime}+a_{-12} a_{02} a_{11}^{\prime}\right)\right\}\right] .
\end{aligned}
$$

Similarly when the lighter component is in trace the rigorous expression of SAXENA and DAvE ${ }^{3,4}$ gets simplified to

$$
\begin{aligned}
{\left[a_{\mathrm{T}}\right]_{2}\left(X_{2} \rightarrow 0\right) } & =\frac{5}{2 \sqrt{2}}\left[a_{22}^{\prime \prime} a_{11}^{\prime \prime}\left(a_{-1-1}^{\prime} a_{-2-2}^{\prime}-a_{-1-2}^{\prime 2}\right)-a_{-1-1}^{\prime} a_{-2-2}^{\prime} a_{12}^{\prime \prime 2}\right]^{-1} \\
& \cdot\left[\left(\frac{M_{1}+M_{2}}{M_{1}}\right)^{\frac{1}{2}}\left\{a_{-1-1}^{\prime} a_{-2-2}^{\prime}\left(a_{22}^{\prime \prime} a_{10}-a_{20} a_{12}^{\prime \prime}\right)-a_{22}^{\prime \prime}\left(a_{-11} a_{-10} a_{-2-2}^{\prime}+a_{1-2} a_{0-2} a_{-1-1}^{\prime}\right)\right\}\right. \\
& \left.+\left(\frac{M_{1}+M_{2}}{M_{2}}\right)^{\frac{1}{2}}\left\{a_{22}^{\prime \prime} a_{11}^{\prime \prime}\left(a_{-10} a_{-2-2}^{\prime}-a_{-20} a_{-1-2}^{\prime}\right)\right\}\right] .
\end{aligned}
$$

It may be pointed out that the eqs. (5) and (6) can also be derived from eqs. (1) to (4) by going to the limiting cases viz., $X_{1} \rightarrow 0$ and $X_{2} \rightarrow 0$, respectively. It is also interesting to note that eqs. (5) and (6) exihibit the same mutual symmetry as the corresponding rigorous expressions.

We can further simplify these expressions by neglecting those terms which contain explicitly the power of $M$ greater than two. Equations (2), (3) and (4) then take the following simpler forms of eqs. (7), (8) and (9), respectively:

$$
\begin{aligned}
& A_{00}^{(2)}=T_{-2-2} T_{-1-1}\left(T_{11} T_{22}-T_{12}^{2}\right)-T_{-1-2}^{2} T_{11} T_{22}, \\
& \begin{aligned}
& A_{01}^{(2)}=M^{3}(1+M)^{-2}\left[T_{-2-2} T_{-1-1} T_{10} T_{22}+(1+M)^{-5} T_{-2-2} T_{-10} T_{-11} T_{22}\right. \\
&\left.+(1+M)^{-9} T_{-20} T_{-21} T_{-1-1} T_{22}\right],
\end{aligned}
\end{aligned}
$$

8 S. C. SAXena and R. K. Joshi, Physica 29, 870 [1963] ; Indian J. Phys. 37, 479 [1963].

9 S. C. Saxena and R. K. Joshi, J. Phys. Soc., Japan 18, 703 [1963].
10 E. A. Mason, J. Chem. Phys. 22, 169 [1954] ; 27, 75, 782 [1957]. 


$$
A_{0-1}^{(2)}=M^{\frac{1}{2}}(1+M)^{-2}\left[T_{11} T_{22}\left\{(1+M)^{-1} T_{-20} T_{-1-2}-T_{-2-2} T_{-10}\right\}\right] .
$$

Here, $T_{10}=T_{-10}=W_{1}, T_{20}=T_{-20}=W_{2}, T_{11}=T_{1}, T_{-1-1}=T_{2}, T_{-11}=P_{1}, T_{12}=T_{3}, T_{-1-2}=T_{4}, T_{1-2}=$ $T_{-12}=P_{2}, T_{22}=T_{5}$, and $T_{-2-2}=T_{6}$. The various $T_{i}, W_{i}$ and $P_{i}$ are as defined earlier by Saxena, Dave and PARDESHI ${ }^{5}$. The reason for introducing this new notation here is that these bear certain relationship with the corresponding $a_{i j}$. In general $T_{i j}=T_{j i}$.

Equations (7), (8) and (9) can also be derived from the eqs. (2), (3) and (4) respectively of Saxena, Dave and PARdeshi ${ }^{5}$ by retaining in the latter equations only those terms which contain the product of two or more diagonal elements.

Equations (5) and (6) can also be further simplified as were eqs. (2) to (4) by retaining only those terms that contain explicitly the power of $M$ as two or less than two. The equations (5) and (6) then take the following form of eqs. (10) and (11) respectively:

$$
\begin{aligned}
{\left[\alpha_{\mathrm{T}}\right]_{2}\left(X_{1} \rightarrow 0\right)=} & \frac{5}{2 \sqrt{2}}\left[T_{11}^{\prime} T_{22}^{\prime}\left(T_{-2-2}^{\prime \prime} T_{-1-1}^{\prime \prime}-T_{-1-2}^{\prime \prime 2}\right)-M^{2} T_{-2-2}^{\prime \prime} T_{-1-1}^{\prime \prime} T_{12}^{\prime 2}\right]^{-1} \\
& \cdot\left[M(1+M) T_{-2-2}^{\prime \prime} T_{-1-1}^{\prime \prime} T_{10} T_{22}^{\prime}+(1+M)^{-3}\left\{(1+M)^{-1} T_{-20} T_{-2-1}^{\prime \prime} T_{11}^{\prime} T_{22}^{\prime}\right.\right. \\
& \left.\left.-T_{22}^{\prime} T_{11}^{\prime} T_{-10} T_{-2-2}^{\prime \prime}-M^{2} T_{-2-2}^{\prime \prime} T_{-11} T_{10} T_{22}^{\prime}\right\}\right]
\end{aligned}
$$

and

$$
\begin{aligned}
& {\left[\alpha_{\mathrm{T}}\right]_{2}\left(X_{2} \rightarrow 0\right)=\frac{5}{2 \sqrt{2}}\left[T_{-2-2}^{\prime} T_{-1-1}^{\prime}\left(T_{11}^{\prime \prime} T_{22}^{\prime \prime}-T_{12}^{\prime \prime 2}\right)-T_{-1-2}^{\prime 2} T_{11}^{\prime \prime} T_{22}^{\prime \prime}\right]^{-1}} \\
& \cdot\left[M ^ { \frac { 3 } { 2 } } ( 1 + M ) ^ { - \frac { 3 } { 2 } } \left\{T_{-2-2}^{\prime} T_{-1-1}^{\prime} T_{10} T_{22}^{\prime \prime}+T_{-2-2}^{\prime} T_{-10} T_{-11} T_{22}^{\prime \prime}\right.\right. \\
& \left.\left.+T_{-20} T_{-1-1}^{\prime} T_{1-2} T_{22}^{\prime \prime}\right\}+(1+M) T_{11}^{\prime \prime} T_{22}^{\prime \prime}\left(T_{-20} T_{-1-2}^{\prime}-T_{-2-2}^{\prime} T_{-10}\right)\right] \text {. }
\end{aligned}
$$

In these equations $T_{11}^{\prime}=Y_{1}, T_{11}^{\prime \prime}=L_{1}, T_{-1-1}^{\prime}=Y_{2}$, $T_{-1-1}^{\prime \prime}=L_{2}, T_{12}^{\prime}=Y_{3}, T_{12}^{\prime \prime}=L_{3}, T_{-1-1}^{\prime}=Y_{4}, T_{-1-2}^{\prime \prime}$ $=L_{4}, T_{22}^{\prime}=Y_{5}, T_{22}^{\prime \prime}=L_{5}, T_{-2-2}^{\prime}=Y_{6}$ and $T_{-2-2}^{\prime \prime}=L_{6}$, where the defining relations for the various $L_{i}$ and $Y_{i}$ are earlier given by SAxena, Dave and Pardeshi ${ }^{5}$. Equations (10) and (11) have been derived from the corresponding rigorous expressions by applying the two types of approximations in a definite order. It may, however, be remarked that the final results remain unaltered even if we reverse the order of applying these approximations. A further point to note in connection with eqs. (10) and (11) is that these no more exhibit that mutual symmetry which was found in the case of eqs. (5) and (6). The reason for this can be traced to the fact that in general the explicit power of $M$ in $a_{i j,}^{\prime}$ and $a_{i j}^{\prime \prime}$ is not the same as those in $a_{-i-j}^{\prime}$ and $a_{-i-j}^{\prime \prime}$ respectively.

\section{Results and Discussion}

It is essential to check the accuracy of the proposed simplified formulae by performing numerical calculations on specific systems. The two systems considered here are Ar-Xe and He-Xe, and the computations of $\left[\alpha_{\mathrm{T}}\right]_{2}$ are done according to the familiar LenNard-Jones $(12: 6)$ potential in conjunction with the parameters reported by SAxena et al. ${ }^{5}$. We also list in each case the calculated values of the first approximation to $\alpha_{\mathrm{T}},\left[\alpha_{\mathrm{T}}\right]_{1}$, with a view to assess the rate of convergence of the higher approximations to $\alpha_{T}$. The expression for $\left[\alpha_{T}\right]_{1}$ is given by Chapman and Cowling ${ }^{1}$.

Computed values of $\left[\alpha_{\mathrm{T}}\right]_{2}$ according to the various expressions given above for the two systems as a function of composition are reported in Table 1. Similar values of $\left[\alpha_{\mathrm{T}}\right]_{2}$ as a function of temperature are listed in Table 2 . Table 3 records the $\left[\alpha_{\mathrm{T}}\right]_{2}$ values for the Ar-Xe system as a function of temperature for the two limiting cases. In Table 4 we report the results for the $\mathrm{He}-\mathrm{Xe}$ system when $\mathrm{He}$ is in trace as a function of temperature.

A critical examination of the entries in Tables 1 and 2 reveals that the procedure suggested here for approximating the Chapman-Cowling determinants is capable of yielding accurate results. The new expression for $\left[\alpha_{T}\right]_{2}$, eqs. (1) to (4), is also much simpler for numerical computations. The calculated values of $\left[\alpha_{\mathrm{T}}\right]_{2}$ for both the systems $\mathrm{He}-\mathrm{Xe}$ and $\mathrm{Ar}$ $\mathrm{Xe}$ agree with the corresponding rigorous values in the entire composition range and the temperature range of Table 1 to much better than $1 \%$.

The further approximated formulae based on the expansion in powers of $M$ are also quite satisfactory and more so in view of their marked simplicity. The disagreement of the calculated values on the basis of these simplified formulae with the rigorous values 


\begin{tabular}{|c|c|c|c|c|c|c|c|c|}
\hline \multirow[b]{2}{*}{$\begin{array}{c}\% \\
\text { Lighter } \\
\text { Com- } \\
\text { ponent }\end{array}$} & \multicolumn{4}{|c|}{$\mathrm{He}-\mathrm{Xe}$} & \multicolumn{4}{|c|}{$\mathrm{Ar}-\mathrm{Xe}$} \\
\hline & $\begin{array}{c}{\left[\alpha_{T}\right]_{1}} \\
\text { eq. (1) }\end{array}$ & $\begin{array}{c}{\left[\alpha_{\mathrm{T}}\right]_{2}} \\
\text { eq. (1) }\end{array}$ & $\begin{array}{c}{\left[\alpha_{\mathrm{T}}\right]_{2}} \\
\text { eqs. }(1) \\
\text { to }(4)\end{array}$ & $\begin{array}{c}{\left[\alpha_{\mathrm{T}}\right]_{2}} \\
\text { eqs. (1) } \\
\text { and }(7) \\
\text { to }(9)\end{array}$ & $\begin{array}{c}{\left[\alpha_{\mathrm{T}}\right]_{1}} \\
\text { eq. (1) }\end{array}$ & $\begin{array}{c}{\left[\alpha_{\mathrm{T}}\right]_{2}} \\
\text { eq. (1) }\end{array}$ & $\begin{array}{c}{\left[\alpha_{\mathrm{T}}\right]_{2}} \\
\text { eqs. }(1) \\
\text { to }(4)\end{array}$ & $\begin{array}{c}{\left[\alpha_{\mathrm{T}}\right]_{2}} \\
\text { eqs. }(1) \\
\text { and }(7) \\
\text { to }(9)\end{array}$ \\
\hline $\begin{array}{l}30 \\
50 \\
70\end{array}$ & $\begin{array}{l}0.3349 \\
0.4125 \\
0.5370\end{array}$ & $\begin{array}{l}0.3581 \dagger \\
0.4381 \\
0.5651\end{array}$ & $\begin{array}{l}0.3583 \\
0.4383 \\
0.5652\end{array}$ & $\begin{array}{l}0.3581 \\
0.4376 \\
0.5651\end{array}$ & $\begin{array}{l}0.1112 \\
0.1229 \\
0.1377\end{array}$ & $\begin{array}{l}0.1110 \\
0.1226 \\
0.1373\end{array}$ & $\begin{array}{l}0.1112 \\
0.1234 \\
0.1381\end{array}$ & $\begin{array}{l}0.1133 \\
0.1233 \\
0.1406\end{array}$ \\
\hline
\end{tabular}

Table 1. Computed values of $\alpha_{\mathrm{T}}$ for the $\mathrm{He}-\mathrm{Xe}$ and $\mathrm{Ar}-\mathrm{Xe}$ systems at $T=316.4{ }^{\circ} \mathrm{K}$ and as a function of composition. Values listed in columns (2), (3), (6), and (7) have been reported earlier by SAXENA, DAve and PArdeshi ${ }^{5}$. $\dagger$ This value was wrongly printed in the earlier work.

\begin{tabular}{|c|c|c|c|c|c|c|c|c|}
\hline \multirow{2}{*}{$\begin{array}{l}\text { Tempe- } \\
\text { rature } \\
{ }^{\circ} \mathrm{K}\end{array}$} & \multicolumn{4}{|c|}{$\mathrm{He}-\mathrm{Xe}(46.4 \% \mathrm{Xe})$} & \multicolumn{4}{|c|}{$\mathrm{Ar}-\mathrm{Xe}(43.6 \% \mathrm{Xe})$} \\
\hline & $\begin{array}{c}{\left[\alpha_{T}\right]_{1}} \\
\text { eq. (1) }\end{array}$ & $\begin{array}{c}{\left[\alpha_{\mathrm{T}}\right]_{2}} \\
\mathrm{eq} \cdot(1)\end{array}$ & $\begin{array}{c}{\left[\alpha_{\mathrm{T}}\right]_{2}} \\
\text { eqs. }(1) \\
\text { to }(4)\end{array}$ & $\begin{array}{c}{\left[\alpha_{\mathrm{T}}\right]_{2}} \\
\text { eqs. }(1) \\
\text { and }(7) \\
\text { to }(9)\end{array}$ & $\begin{array}{c}{\left[\alpha_{\mathrm{T}}\right]_{1}} \\
\mathrm{eq} \cdot(1)\end{array}$ & $\begin{array}{c}{\left[\alpha_{\mathrm{T}}\right]_{2}} \\
\mathrm{eq} \cdot(1)\end{array}$ & $\begin{array}{c}{\left[\alpha_{\mathrm{T}}\right]_{2}} \\
\text { eqs. (l) } \\
\text { to }(4)\end{array}$ & $\begin{array}{c}{\left[\alpha_{\mathrm{T}}\right]_{2}} \\
\text { eqs. (1) } \\
\text { and }(7) \\
\text { to }(9)\end{array}$ \\
\hline 185 & - & - & - & - & 0.02718 & 0.02583 & 0.02602 & 0.02623 \\
\hline 233 & 0.4038 & 0.4252 & 0.4252 & 0.4253 & - & - & - & - \\
\hline 293 & 0.4238 & 0.4480 & 0.4478 & 0.4479 & 0.1099 & 0.1082 & 0.1082 & 0.1096 \\
\hline 369 & 0.4398 & 0.4680 & 0.4684 & 0.4684 & 0.1543 & 0.1542 & 0.1554 & 0.1562 \\
\hline 585 & 0.4654 & 0.5122 & 0.5133 & 0.5121 & 0.2264 & $0.2316 \dagger$ & 0.2319 & 0.2349 \\
\hline
\end{tabular}

Table 2. Computed values of $\alpha_{\mathrm{T}}$ for the $\mathrm{He}-\mathrm{Xe}$ and $\mathrm{Ar}-\mathrm{Xe}$ systems as a function of temperature. Values listed in columns $(2),(3),(6)$, and (7) have been reported earlier by SAXENA, D Ave and PARDESHI ${ }^{5}$. $\dagger$ This value was wrongly printed in that work.

\begin{tabular}{|c|c|c|c|c|c|c|c|c|}
\hline \multirow{2}{*}{$\begin{array}{l}\text { Tempe- } \\
\text { rature } \\
{ }^{\circ} \mathrm{K}\end{array}$} & \multicolumn{4}{|c|}{$\mathrm{Xe}$ in trace } & \multicolumn{4}{|c|}{ Ar in trace } \\
\hline & $\begin{array}{c}{\left[\alpha_{\mathrm{T}}\right]_{1}} \\
\text { eq. (1) }\end{array}$ & $\begin{array}{c}{\left[\alpha_{\mathrm{T}}\right]_{2}} \\
\mathrm{eq} \cdot(\mathbf{l})\end{array}$ & $\begin{array}{c}{\left[\alpha_{\mathrm{T}}\right]_{2}} \\
\text { eqs. (5) }\end{array}$ & $\begin{array}{c}{\left[\alpha_{\mathrm{T}}\right]_{2}} \\
\text { eq. }(10)\end{array}$ & $\begin{array}{c}{\left[\alpha_{\mathrm{T}}\right]_{1}} \\
\text { eq. }(1)\end{array}$ & $\begin{array}{c}{\left[\alpha_{\mathrm{T}}\right]_{2}} \\
\text { eq. (1) }\end{array}$ & $\begin{array}{c}{\left[\alpha_{\mathrm{T}}\right]_{2}} \\
\mathrm{eq} \cdot(6)\end{array}$ & $\begin{array}{c}{\left[\alpha_{\mathrm{T}}\right]_{2}} \\
\mathrm{eq} \cdot(11)\end{array}$ \\
\hline 100 & -0.04160 & -0.03775 & -0.03777 & -0.03778 & -0.02496 & -0.02337 & -0.02308 & -0.02309 \\
\hline 300 & - & - & - & - & 0.08958 & $0.08939 \dagger$ & 0.08986 & 0.08994 \\
\hline 500 & 0.2721 & 0.2749 & 0.2746 & 0.2743 & - & - & - & - \\
\hline 900 & 0.3464 & 0.3556 & 0.3560 & 0.3556 & 0.2062 & $0.2123 \dagger$ & 0.2146 & 0.2145 \\
\hline
\end{tabular}

Table 3. Computed values of $\alpha_{\mathrm{T}}$ for $\mathrm{Ar}-\mathrm{Xe}$ system as a function of temperature when either of the component is in trace. Values listed in columns (2) and (3) have been reported earlier by SAXENA and D DVE 2 and those in columns (6) and (7) by SAXENA and DAVE ${ }^{5}$. $\dagger$ These values were printed wrongly in those works.

\begin{tabular}{|c|c|c|c|c|}
\hline $\begin{array}{c}\text { Tempe- } \\
\text { rature } \\
{ }^{\circ} \mathrm{K}\end{array}$ & $\begin{array}{c}\mid 4 \\
{\left[\alpha_{\mathrm{T}}\right]_{1}} \\
\text { eq. (1) }\end{array}$ & $\begin{array}{c}{\left[\alpha_{\mathrm{T}}\right]_{2}} \\
\text { eq. (1) }\end{array}$ & $\begin{array}{c}{\left[\alpha_{\mathrm{T}}\right]_{2}} \\
\text { eq. (6) }\end{array}$ & $\begin{array}{c}{\left[\alpha_{\mathrm{T}}\right]_{2}} \\
\text { eq. (11) }\end{array}$ \\
\hline 500 & 0.2835 & 0.3089 & 0.3097 & 0.3089 \\
700 & 0.2878 & 0.2950 & 0.2966 & 0.2966 \\
900 & 0.2850 & 0.3181 & 0.3205 & 0.3181 \\
\hline
\end{tabular}

Table 4. Computed values of $\alpha_{\mathrm{T}}$ for the $\mathrm{He}-\mathrm{Xe}$ system as a function of temperature when He is in trace. Values listed in columns (2) and (3) have been reported earlier by SAxena and $\mathrm{D}_{\mathrm{AvE}}{ }^{3,4}$.

just starts getting pronounced for the Ar-Xe system. This, however, is not suprising in view of the large $M$ value for this system.

Tables 3 and 4 present the results for these two systems when one of the components is in trace. The same sort of qualitative conclusions follow here also as in the general case.

In conclusion we suggest the use of this particular procedure for approximating the Chapman-CowLING determinants which occur in higher approximations to $\alpha_{T}$ and other transport coefficients. The simpler expressions for $\left[\alpha_{\mathrm{T}}\right]_{2}$ derived in this paper will be useful in predicting the values of $\alpha_{T}$ for unknown systems or for determining the potential energy functions if the experimental $\alpha_{T}$ data be available.

It will be interesting to have a relative assessment of the various simpler $\alpha_{\mathrm{T}}$ formulae derived here and those given in the previous papers. We feel that for those systems for which $M$ is small ( $\leqq 1 / 30$, say) 
the formulae derived by Saxena, Dave and ParDESHI ${ }^{5}$ for the general case and by SAXENa and $D_{A v E}{ }^{2-4}$ for the limiting cases will be satisfactory and dependable in accuracy because these are based on a well defined approximation scheme. If the value of $M$ is somewhat higher slightly modified versions of these formulae given by SAxena and Joshi ${ }^{6,7}$ may be employed. When the value of $M$ becomes still larger $(\geqq 1 / 4)$ these formulae will not be always adequate and we suggest the use of simpler formulae given by eqs. (1) to (6) of this paper for the various types of binary mixtures. Some caution is required in the use of these formulae as their derivation is based on an empirical assumption i.e. the nondiagonal elements are smaller than the diagonal elements of Chapman-Cowling determinants. Calculations performed so far support this viewpoint. If this approximation is valid for a particular system and its value of $M$ is also low the doubly approximated formulae given by eqs. (1) and (7) to (11) of this paper will be the simplest and hence most preferable for use.

\title{
Massenspektrometrische Untersuchung der Feldionisation von Wasserdampf an Spitzen aus Wolfram, Platin und Iridium ${ }^{1,2}$
}

\author{
Von W. A. Sснмidt \\ Fritz-Haber-Institut der Max-Planck-Gesellschaft, Berlin \\ (Z. Naturforschg. 19 a, 318-327 [1964] ; eingegangen am 23. November 1963)
}

\begin{abstract}
Mit einem Feldionisations-Massenspektrometer wurden die Ionen registriert, die sich an Spitzen aus $\mathrm{W}, \mathrm{Pt}$, Ir bilden, wenn $\mathrm{H}_{2} \mathrm{O}$-Dampf in die Ionenquelle eingelassen wird. Die Ionenströme setzten oberhalb einer für das jeweilige System charakteristischen Grenzfeldstärke sprunghaft ein (W-Spitze $/ \mathrm{H}_{2} \mathrm{O}: 20 \mathrm{MV} / \mathrm{cm}$, Ir-Spitze $/ \mathrm{H}_{2} \mathrm{O}: 51 \mathrm{MV} / \mathrm{cm}$, Pt-Spitze $/ \mathrm{H}_{2} \mathrm{O}: 61 \mathrm{MV} / \mathrm{cm}$ ). Die Feldstärkeabhängigkeit der Spektren wurde systematisch gemessen (Spitze jeweils auf Zimmertemperatur). Beim System W/ $\mathrm{H}_{2} \mathrm{O}$ traten neben den schon bekannten Ionenarten $\mathrm{H}_{3} \mathrm{O}^{+} \cdot\left(\mathrm{H}_{2} \mathrm{O}\right)_{n}, n=0,1,2,3$ Ionen von Wolframoxyden in verschiedenen Oxydations- und Ionisierungsstufen mit und ohne angelagerte $\mathrm{H}_{2} \mathrm{O}$-Moleküle auf. Bei $\mathrm{Pt} / \mathrm{H}_{2} \mathrm{O}$ und $\mathrm{Ir} / \mathrm{H}_{2} \mathrm{O}$ wurden bei der Einsatzfeldstärke die Ionen $\mathrm{H}_{3} \mathrm{O}^{+} \cdot\left(\mathrm{H}_{2} \mathrm{O}\right)_{n}, n=0,1,2$ gemessen. Bei höheren Feldstärken traten zusätzlich $\mathrm{H}_{2} \mathrm{O}^{+}$und $\mathrm{O}_{2}^{+}$auf, hingegen keine Metalloxydionen.

Es wird gezeigt, daß der sprunghafte Ionenstromeinsatz durch die Existenz einer für den Tunneleffekt notwendigen Abstandsbedingung hervorgerufen sein könnte. Bereits bei der Einsatzfeldstärke liegen die Ionisierungswahrscheinlichkeiten von $\mathrm{H}_{2} \mathrm{O}$ in der Nähe von eins. Der Reaktionsmechanismus bei der Feldionisierung des $\mathrm{H}_{2} \mathrm{O}$, das nach den experimentellen Ergebnissen als mehrmolekulare Adsorptionsschicht die Spitzen bedeckt, sowie die Intensitätsabhängigkeit der einzelnen Ionenarten von der Feldstärke werden diskutiert.
\end{abstract}

Der Gedanke, die an einer Spitze unter dem Einfluß hoher elektrischer Felder gebildeten Ionen massenspektrometrisch zu untersuchen, ist etwa gleichzeitig an drei verschiedenen Stellen aufgetreten $^{3-5}$.

Bei den zum Zeitpunkt der Themenstellung (1959) schon vorliegenden, mit dem Massenspektrometer durchgeführten Feldionisierungsuntersuchungen wurden ausschließlich Spitzen aus Wolfram benutzt, wobei der Spitze allein die Funktion einer felderzeugenden Elektrode beigemessen wurde ${ }^{6-8}$. Mit der vorliegenden Arbeit sollte entschieden werden, ob im Feldionen-Massenspektrum Ionenarten angezeigt

1 W. A. Schмid, Phys. Verh. 12, 71 [1961].

2 W. A. Sснмгдт, Dissertation, Freie Universität Berlin 1962.

${ }^{3}$ E. W. Müller ${ }^{7}$, vgl. auch Zitat ${ }^{14}$.

4 M. G. Inghram u. R. Gomer, J. Chem. Phys. 22, 1279 [1954]. werden, deren Existenz auf einen Einfluß des Spitzenmaterials zurückzuführen ist. Über die an WolframSpitzen gebildeten Feldionen von Wasserdampf lagen bereits Messungen von Beckey ${ }^{8}$ vor. Diese Messungen wurden in verschiedener Richtung erweitert und mit Messungen, die bei Verwendung von Platin- und Iridium-Spitzen erhalten wurden, verglichen.

\section{A. Versuchsdurchführung}

Es wurde ein $60^{\circ}$-Sektorfeld-Massenspektrometer benutzt mit einem Sekundärelektronenvervielfacher als Detektor. Die Feldemissions-Ionenquelle war eine fo-

${ }^{5}$ M. Drechsler, DBP Nr. 954 105, angem. am 2. 7. 1954.

6 M. G. Inghram u. R. Gomer, Z. Naturforschg. 10 a, 863 [1955].

7 E. W. Müller u. K. Bahadur, Phys. Rev. 102, 624 [1956].

8 H. D. BECKEY, Z. Naturforschg. 14 a, 712 [1959]. 